\title{
POSUNY V PRÁVU EVROPSKÉ UNIE A JEHO IMPLEMENTACI V NÁVAZNOSTI NA LISTINU ZÁKLADNÍCH PRÁV EU VE SROVNÁNÍ S OBDOBÍM PŘED LISTINOU
}

\author{
MARKÉTA WHELANOVÁ
}

\begin{abstract}
Trends in EU law and its implementation following the Charter of Fundamental Rights of the EU

Impacts of the Charter of Fundamental Rights of the EU differ in various sources of EU law. While in the contemporary case law one can find detailed arguments based on the Charter, in the recitals of secondary legislation often appear mere formal and superficial estimations of proposed provisions from the Charter's point of view.

Older case law put a strong emphasis on common principles and human rights. Principles comparable to the ones of the Charter therefore emerged well before the adoption of the Charter.

To conclude, impacts in the Charter of Fundamental Rights of the EU are not so distinctive in comparison with the impacts of former EU law preceding the Charter as a binding source of law which was based on common principles and human rights.
\end{abstract}

Keywords: Charter of Fundamental Rights of the EU; case law; secondary legislation; after Lisbon period; period preceding the legally binding character of the Charter

Klíčová slova: Listina základních práv EU; judikatura; sekundární legislativa; polisabonské období; období před zezávazněním Listiny

DOI: $10.14712 / 23366478.2018 .31$

\section{1. ÚVOD}

Praktické dopady Listiny základních práv EU je př́hodné zkoumat rovněž z pohledu implementace práva EU do vnitrostátních právních řádů. Je tedy na místě položit si otázku, nakolik Listina základních práv EU ovlivňuje samotné právo EU a následně pak jeho implementaci v jednotlivých členských státech EU, a nakolik jsou př́ipadné posuny výrazné ve srovnání s dřívějším stavem práva EU.

\section{VLIV LISTINY ZÁKLADNÍCH PRÁV EU NA PRÁVO EU}

Článek 6 odst. 1 Smlouvy o Evropské unii, ve znění Lisabonské smlouvy uvádí, že „Unie uznává práva, svobody a zásady obsažené v Listině základních práv 
Evropské unie ze dne 7. prosince 2000, ve zněni upraveném dne 12. prosince 2007 ve Štrasburku, jež má stejnou právní sílu jako Smlouvy“. Tato deklarace ukazuje na to, že se předpokládá výrazné ovlivňování nově přijímaných pramenů práva EU Listinou základních práv EU. To je nejvíce patrné v př́ipadě judikatury Soudního dvora EU, ve které je argumentace Listinou základních práv EU poměrně častá.

\subsection{JUDIKATURA SOUDNÍHO DVORA EU V POLISABONSKÉM OBDOBÍ}

Př́kladmo je možno upozornit na několik rozhodnutí Soudního dvora EU

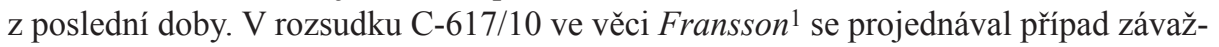
ných daňových úniků, které byly předmětem sankcí v podobě daňových přirážek; problém vyvstal tehdy, když vyšlo najevo, že daňové úniky jsou i předmětem jiného ř́izení, které má trestněprávní charakter. Bylo totiž sporné, zda se nejedná o porušení zásady ne bis in idem, která je začleněna mj. do čl. 50 Listiny základních práv EU. ${ }^{2}$

Soudní dvůr Evropské unie $\mathrm{v}$ uvedeném případě uvedl, že uplatnění zásady ne bis in idem $\mathrm{v}$ čl. 50 Listiny základních práv EU vyžaduje, aby opatření, která byla přijata vůči obviněnému prostřednictvím konečného rozhodnutí, měla trestněprávní povahu. Proto, dle jeho závěru, zásada ne bis in idem uvedená v článku 50 Listiny nebrání tomu, aby členský stát uložil za totéž jednání spočívající v povinnosti podat přiznání k DPH postupně daňovou (správní) a trestní sankci, jestliže první zmíněná sankce nemá trestní povahu (viz bod 33 a 37 rozsudku).

V dalším sporu v oblasti daňové, rozsudku C-682/15 ve věci Berlioz, ${ }^{3}$ byla ve hře Listina základních práv EU v souvislosti s interpretací směrnice Rady 2011/16/EU o správní spolupráci v oblasti daní. ${ }^{4} \mathrm{~V}$ uvedené věci francouzská daňová správa žádala lucemburskou daňovou správu o informace podle výše uvedené směrnice, nebot' měla pochybnosti, zda lucemburská společnost Berlioz a její dceřiná společnost Cofina založená podle francouzského práva dodržují francouzské právo týkající se osvobození od srážkové daně. V návaznosti na to bylo společnosti Berlioz uloženo, aby sdělila dodatečné informace. Společnost Berlioz na uvedenou výzvu reagovala, určité informace, mj. jména a adresy společníků, jakož i výši jejich podílů, však odmítla uvést s tím, že se nejedná o informace, které by byly významné pro posouzení z hlediska směrnice 2011/16/EU. Pouze částečné vyhovění informační povinnosti společností Berlioz bylo ze strany finančních orgánů sankcionováno pokutou. Společnost Berlioz proti rozhodnutí o uložení sankce podala žalobu k lucemburskému soudu. Uvedený soud sice pokutu snížil, odmítl ale ověřit opodstatněnost rozhodnutí o povinnosti sdělit dodatečné informace. Předmětem rozhodování Soudní dvora tak bylo zejména to, zda v př́ípadě dožá-

C-617/10 Åklagaren v. Hans Åkerberg Fransson, ECLI:EU:C:2013:105.

2 K uvedené věci se vztahuje kritika, že vazba na právo EU není v tomto prŕípadě jednoznačná. Soudní dvůr totiž stanovil, že členské státy jednají v působnosti práva EU i tehdy, když neprovádějí či neuplatňují určitou normu práva EU. Srov. ŠMEJKAL, V.: Listina základních práv EU jako nástroj budování sociálního systému EU? Právník, 2016, č. 6, s. 495-496.

3 C-682/15 Berlioz Investment Fund S.A. v. Directeur de l'administration des contributions directes, ECLI: EU:C:2017:373.

4 Směrnice Rady 2011/16/EU ze dne 15. 2. 2011 o správní spolupráci v oblasti daní a o zrušení směrnice 77/799/EHS, Úr. věst. L 64, 11. 3. 2011, s. 1-12. 
dání v daňových věcech dle př́ślušné směrnice EU, které vyústí v uložení sankce, musí být zároveň zachováno právo osoby na právní ochranu. ${ }^{5}$ Soudní dvưr ve svém rozsudku uvedl, s odvoláním na čl. 47 Listiny základních práv EU, že adresát rozhodnutí, kterým mu byla uložena peněžitá sankce za nesplnění povinnosti poskytnout informace $\mathrm{v}$ rámci výměny informací mezi daňovými správami dle směrnice 2011/16/EU, může v rámci práva na právní ochranu zpochybnit legalitu daného rozhodnutí. Legalita uvedeného rozhodnutí přezkoumávaná soudem pak má být omezena na ověření zjevné neexistence významu požadovaných informací pro potřeby daného daňového šetření. $\mathrm{V}$ tom je třeba spatřovat posun oproti dřívějšímu ,,českému“ rozsudku C-276/12 ve věci Sabou, ${ }^{6}$ který byl ale zaměřen na to, zda má daňový subjekt právo podílet se na výměně informací mezi orgány, a otázka napadnutí předávaných, resp. poskytovaných informací, byla $\mathrm{v}$ této věci řešena pouze rámcově $\mathrm{s}$ odkazem na úpravu ve vnitrostátním právu každého členského státu.

„Penalizační“ předmět sporu měl i rozsudek Soudního dvora C-399/11 ve věci Melloni. ${ }^{7}$ Zde byl projednáván př́ípad výkonu evropského zatýkacího rozkazu vydaného na pana Melloniho italskými orgány podle rámcového rozhodnutí Rady 2002/584/SVV o evropském zatýkacím rozkazu a postupech předávání mezi členskými státy, ${ }^{8}$ a to za účelem výkonu trestu odnětí svobody uloženého v nepř́itomnosti. Ve hře byla úprava čl. 4a uvedeného rámcového rozhodnutí, která omezovala možnost odmítnutí výkonu evropského zatýkacího rozkazu v neprrítomnosti tak, aby nedocházelo k obcházení jeho účelu ze strany obviněných osob. Soudní dvůr EU označil uvedenou úpravu za slučitelnou s čl. 47 a 48 odst. 2 Listiny základních práv EU, které zaručují právo na obhajobu a řádné projednání věcí před nezávislými a nestrannými soudy. Na druhou stranu uvedl, že v rozporu s čl. 53 Listiny, který zakazuje snížení ochrany lidských práv, by bylo podmíněné předání osoby odsouzené v nepřítomnosti s tím, že odsuzující rozhodnutí může být ve vystavujícím členském státě přezkoumáno za účelem vyloučení zásahu do práva na spravedlivý proces a práva na obhajobu.

V rozsudku C-578/16 PPU ve věci C.K. a dalši proti Republika Slovenija $a^{9}$ byl dále vykládán zejména čl. 4 Listiny základních práv EU zakazující mučení a nelidské či ponižující zacházení nebo trest, a to v rámci azylového rrízení podle nařízení č. 604/2013 (Dublin III). ${ }^{10}$ Bylo totiž sporné, nakolik přemístění žadatelky o azyl v pokročilém stádiu těhotenství a následně po porodu ze Slovinska zpět do Chorvatska bude mít negativní následky na její zdravotní stav. Soudní dvůr přenechal ověření zdravotního stavu žadatelky o azyl vnitrostátnímu soudu (bod 90 rozsudku), uvedl ale základní kritéria

5 K právu na obhajobu a účinnou právní ochranu podle čl. 47 Listiny viz rovněž rozsudek Soudního dvora (čtvrtého senátu) C-418/11 Texdata Software GmbH, ECLI:EU:C:2013:588.

6 C-276/12 Jiři Sabou proti Finanční réeditelství pro hlavní město Prahu, ECLI:EU:C:2013:678.

7 C-399/11 Stefano Melloni v. Ministerio Fiscal, ECLI:EU:C:2013:107.

8 Rámcové rozhodnutí Rady ze dne 13. 6. 2002 o evropském zatýkacím rozkazu a postupech předávání mezi členskými státy, Úř. věst. L 190, 18. 7. 2002, s. 1-20, zvláštní vydání v českém jazyce: Kapitola 19, svazek 006, s. 34-51.

9 C-578/16 PPU C. K. a dalši v. Republika Slovenija, ECLI:EU:C:2017:127.

10 Nařízení Evropského parlamentu a Rady (EU) č. 604/2013 ze dne 26. 6. 2013, kterým se stanoví kritéria a postupy pro určení členského státu př́íslušného k posuzování žádosti o mezinárodní ochranu podané státním příslušníkem třetí země nebo osobou bez státní prř́slušnosti v některém z členských států, Ưř. věst. L 180, 29. 6. 2013, s. 31-59. 
pro to, jak má být postupováno, aby nedošlo k porušení Listiny základních práv EU. Nejsou-li závažné důvody domnívat se, že v členském státě př́íslušném k posouzení žádosti o azyl dochází k systematickým nedostatkům, lze dle soudu přemístění žadatele o azyl podle nařízení Dublin III provést pouze za podmínek, které vylučují, že přemístění sebou ponese skutečné a prokázané riziko vystavení dotyčné osoby nelidskému či ponižujícímu zacházení ve smyslu čl. 4 Listiny základních práv EU. Takové riziko nastává tehdy, když hrozí značné a nevratné zhoršení zdravotního stavu osoby.

V neposlední řadě je vhodné upozornit i na rozsudek C-293/12 a C-594/12 ve věci Digital Rights Ireland Ltd ${ }^{11}$ a rozsudek ve věci C-203/15 Tele $2 .{ }^{12} \mathrm{~V}$ obou př́padech se jednalo o to, nakolik je plošné a nerozlišující uchovávání veškerých provozních a lokalizačních údajů pro účely boje proti trestné činnosti v souladu s požadavky čl. 7 a 8 Listiny základních práv EU týkající se respektování soukromého života a ochrany osobních údajů, př́padně s čl. 11 garantujícím svobodu projevu, a to ve spojení s čl. 52 Listiny upravující zásadu přiměřenosti. Uvedené uchovávání totiž bylo dříve prováděno mj. na základě směrnice 2006/24 o uchovávání údajů v souvislosti s poskytováním elektronických komunikací nebo komunikačních sítí; ${ }^{13}$ tuto směrnici však Soudní dvůr EU v dubnu 2014 rozsudkem ve věci Digital Rights Ireland Ltd prohlásil za neplatnou právě pro rozpor s Listinou základních práv EU a zásadou proporcionality. Právní názor uvedený již v rozsudku Digital Rights Ireland Ltd Soudní dvůr podržel i ve věci Tele 2. Uvedl, že plošné a nerozlišující uchovávání veškerých provozních a lokalizačních údajů, které nestanovuje žádné omezení, rozlišení nebo výjimky činěné v závislosti na sledovaném cíli, překračuje meze toho, co je nezbytné, a nelze je považovat za odůvodněné.

Vedle uvedeného není možno pominout ani oblast zákazu diskriminace. Z poslední doby je možno zmínit rozsudek C-406/15 ve věci Pet’a Milkova, ${ }^{14}$ který se týkal bulharské právní úpravy, která stanovila specifickou ochranu pro př́ípad propuštění zaměstnanců se zdravotním postižením z pracovněprávního poměru, ale tuto ochranu již nevztáhla na zaměstnance s týmž postižením ve služebním poměru. Soudní dvưr uvedený př́pad rozhodoval i s ohledem na čl. 20 a 21 Listiny základních práv EU, které se týkají ochrany před diskriminací. Uvedl, že takové rozlišení možné je, pokud je obhajitelné z hlediska naplnění zásady rovného zacházení, což musí ověřit vnitrostátní soud. Při porovnávání rozdílů mezi situací osoby v pracovním a služebním poměru přitom musí být analyzována všechna relevantní ustanovení vnitrostátního práva, která upravují postavení pracovníků se stejným zdravotním postižením, a to zejména s přihlédnutím k účelu ochrany proti propuštění. Pokud by z takové analýzy vyplynulo, že není dodržena zásada rovného zacházení, vyžadovala by povinnost dodržovat unijní právo, aby byla působnost vnitrostátních ustanovení na ochranu zaměstnanců s určitým zdravotním

11 C-293/12 a C-594/12 Digital Rights Ireland Ltd v. Minister for Communications, Marine and Natural Resources a dalši a Kärntner Landesregierung a dalši, ECLI:EU:C:2014:238.

12 C-203/15 a C-698/15 Tele2 Sverige AB a Secretary of State for the Home Department v. Post-och telestyrelsen a další, ECLI:EU:C:2016:970.

13 Směrnice Evropského parlamentu a Rady 2006/24/ES ze dne 15. 3. 2006 o uchovávání údajů vytvářených nebo zpracovávaných v souvislosti s poskytováním veřejně dostupných služeb elektronických komunikací nebo veřejných komunikačních sítí a o změně směrnice 2002/58/ES, Úř. věst. L 105, 13. 4. 2006, s. 54-63.

14 C-406/15 Pet'a Milkova v. Izpalnitelen direktor na Agenciata za privatizacia i sledprivatizacionen kontrol, ECLI:EU:C:2017:198. 
postižením $\mathrm{v}$ pracovněprávním poměru rozšířena tak, že se budou tato ochranná ustanovení vztahovat i na zaměstnance s týmž zdravotním postižením ve služebním poměru.

\subsection{ZÁVĚRY VYPLÝVAJÍCÍ Z JUDIKATURY SOUDNÍHO DVORA EU V POLISABONSKÉM OBDOBÍ}

Zdá se tedy zatím, že „nový rozměr“, který představuje Listina základních práv EU, se výrazněji dotýká takových oblastí, jako je správní trestání (zejm. v daňových věcech) či obecněji zásahů státu do sféry práv jednotlivců, nejvíce u azylových záležitostí, a rovněž i obecného naplnění zásady zákazu diskriminace. ${ }^{15}$ Listina jako rámec, či př́padně korekce, je přitom systematicky brána $\mathrm{v}$ potaz a analyticky rozebírána $\mathrm{v}$ jednotlivých relevantních př́padech. Lze předpokládat, že tento trend bude pokračovat i v budoucnu, a, s ohledem na přetrvávající problémy týkající se migračních otázek, výrazně zasáhne cizineckou a azylovou problematiku. ${ }^{16}$

\subsection{SEKUNDÁRNÍ LEGISLATIVA EU V POLISABONSKÉM OBDOBÍ}

Na druhou stranu je však nutno podotknout, že sekundární legislativa Evropské unie se ne vždy důsledně zaobírá vztahem $\mathrm{k}$ Listině základních práv EU. Zdá se, že i přses snahu unijních institucí, zejména Evropské komise, není dosažení systematického analytického posuzování jednoduchou záležitostí. ${ }^{17}$ Je totiž možné najít nové evropské předpisy, které upravují poměrně zásadní právní vztahy týkající se i oblasti lidských práv a které zmiňují Listinu (respektive kontext základních práv) spíše formálně, bez podrobnějšího rozboru př́ípadných limitů, jež stanoví. Jak uvádí studie z roku 2016 The Implementation of the Charter of Fundamental Rights in the EU Institutional Framework, nebyl v dopadových studiích mezi lety 2011 a 2014 v 19 př́padech mezi 35 zkoumanými dostatečně zohledněn dopad na základní práva, přičemž chybělo i uvedení toho, proč základní práva nebyla vzata v úvahu. ${ }^{18}$ Objevují se rovněž silné výtky týkající se nedostatečného zohlednění základních sociálních práv při vytváření a aplikaci norem tvořících Eurozónu. ${ }^{19}$

15 Srov. FUEREA, A.: The current status of the fulfillment of the fundamental rights and freedoms in the European Union. Cross-border Journal of International Studies, 2016, č. 1, s. 57-64.

16 Srov. např. i předběžná otázka českého Nejvyššího správního soudu ze dne 15. prosince 2017 ve věci C-704/17 D. H. v. Ministerstvo vnitra.

17 Viz Sdělení Komise Strategy for the effective implementation of the Charter of Fundamental Rights by the European Union. Brussels, 19. 10. 2010, COM(2010) 573 final. Podle tohoto sdělení by návrhy týkající se základních práv měly v preambuli obsahovat odůvodnění slučitelnosti návrhu s Listinou, k němuž jako podklad slouží tzv. Check-List, kontrolní seznam zabývající se nejdůležitějšími aspekty daného základního práva dotčeného návrhem. Udržení standardu přezkumu slučitelnosti s Listinou pak má dle tohoto sdělení úskalí v př́ípadech, kdy dochází k úpravám návrhu během legislativního procesu (viz kapitola 1.2 sdělení).

18 Zmíněná studie je dostupná na http://www.europarl.europa.eu/RegData/etudes/STUD/2016/571397 /IPOL_STU(2016)571397_EN.pdf, uvedený závěr vyplývá z kapitoly 1.5.2. této studie. Na druhou stranu studie vyzdvihuje to, že jednotlivé instituce EU mají nastaveny mechanismy posuzování slučitelnosti s Listinou a základními právy obecně.

19 PYE, R.: The EU and the absence of fundamental rights in the Eurozone: a critical perspective. European Journal of International Relations, 2017, s. 1-25. 
Určitou kritiku je nutné připustit; mezi nedávno přijatými předpisy Evropské unie je např́ílad možno důvodně pochybovat, nakolik byla Listina základních práv EU brána v potaz při tvorbě směrnice Rady (EU) 2016/2258, tzv. směrnice DAC V. ${ }^{20}$ Účel této směrnice přitom není o nic menší, než poskytnout daňovým orgánům př́stup $\mathrm{k}$ informacím uvedeným v některých článcích směrnice 2015/849 o předcházení využívání finančního systému k praní peněz nebo financování terorismu. ${ }^{21}$ Směrnice DAC V tak podstatným způsobem rozšiřuje osobní působnost v rámci výměny informací mezi členskými státy Evropské unie v oblasti daní, nebot' nově se tato výměna týká nejen finančních institucí, ale všech povinných osob v oblasti předcházení praní peněz, tj. advokátů, notářů, daňových poradců, a to včetně jejich rodinných příslušníků. Důsledkem je to, že pro účely výměny informací mezi členskými státy v oblasti daní, tj. v přeshraničních vztazích, směrnice fakticky prolamuje povinnost mlčenlivosti i u uvedených právnických profesí. To je bezpochyby nutno považovat za velký zásah do jejich vztahu důvěrnosti s klientem, a potažmo výkonu jejich povolání. Tento zásah však nebyl v preambuli směrnice DAC V nijak podrobněji analyzován, a to ani z hlediska čl. 47 Listiny, který mj. stanoví, že „, každý má možnost nechat si poradit, dát se obhajovat či zastupovat“. Směrnice DAC V pouze v bodě 6 preambule stanoví: ,, Tato směrnice dodržuje základní práva a ctí zásady uznané Listinou základních práv Evropské unie. Aniž je dotčen ústavni pořádek dotyčného členského státu, jestliže tato směrnice vyžaduje, aby byl př̀stup daňových orgánů $k$ osobním údajưm zajištěn ze zákona, neni k tomu nutně zapotřebí akt parlamentu. V souladu s judikaturou Soudního dvora Evropské unie a Evropského soudu pro lidská práva by však takový zákon mèl být jasný a přesný a jeho uplatňování by mělo být pro osoby, jichž se týká, jasné a predvídatelné. " To bezpochyby není možno považovat za dostatečné.

Poměrná stručnost vyjádření ohledně vztahu k Listině základních práv EU je běžná i u jiných předpisů EU. Např́klad nařízení Dublin III, ${ }^{22}$ které je významným předpisem EU z oblasti azylového práva, prakticky pouze $\mathrm{v}$ bodě 39 své preambule zmiňuje konkrétní kontext lidských práv v návaznosti na Listinu, když stanoví:

„Toto nařizení dodržuje základni práva a ctí zásady, které jsou uznány zejména $v$ Listině základnich práv Evropské unie. Tímto nařizením by zejména mělo být zajištěno plné dodržování práva na azyl, jak je zaručeno $v$ článku 18 Listiny, a práv uznaných $v$ článcích 1, 4, 7, 24 a 47 Listiny. Toto nařizení by proto mělo být uplatňováno odpovídajicím zpi̊sobem. " Je ale nutno vzít v potaz, že v některých oblastech, mezi které je bezpochyby nutné zařadit azylové věci, je posuzování referenčního rámce lidských práv nelehkou a značně odbornou záležitostí. Zřejmě i proto se objevují názory, že by při posuzování slučitelnosti návrhů předpisů Evropské unie s Listinou mělo být více využíváno služeb Agentury pro lidská práva (Fundamental Rights Agency), mezi je-

20 Směrnice Rady (EU) 2016/2258 ze dne 6. 12. 2016, kterou se mění směrnice 2011/16/EU, pokud jde o př́stup daňových orgánů k informacím pro boj proti praní peněz, Úř. věst. L 342, 16. 12. 2016, s. $1-3$.

21 Směrnice Evropského parlamentu a Rady (EU) 2015/849 ze dne 20. 5. 2015 o předcházení využívání finančního systému k praní peněz nebo financování terorismu, o změně nařizení Evropského parlamentu a Rady (EU) č. 648/2012 a o zrušení směrnice Evropského parlamentu a Rady 2005/60/ES a směrnice Komise 2006/70/ES, Úř. věst. L 141, 5. 6. 2015, s. 73-117.

22 Viz pozn. č. 10. 
jíž úkoly patří i vytváření a publikování závěrů a stanovisek týkajících se speciálních témat. ${ }^{23}$ Odůvodňování souladu s Listinou je rovněž v př́ípadě tvorby legislativy ve srovnání s judikaturou složitější a komplexnější záležitostí, nebot' se nemůže zaměřovat pouze na okolnosti specifického př́ipadu, ale musí vyhodnocovat předem neurčený počet různých situací.

Z výše uvedeného je patrné, že je poměrně značný rozdíl mezi tím, jak dnes uplatňuje Listinu Soudní dvůr EU, a tím, jak je Listina uplatňována Evropskou komisí, Radou a Evropským parlamentem při přijímání legislativy EU. V druhém př́ípadě, i přes snahu při přijímání evropské legislativy brát ohled na kontext lidských práv, ${ }^{24}$ se nezdá, že by Listina vždy byla výrazným ,,referenčním rámcem“, a je tudíž nutno připustit, že uplatňování Listiny je v tomto př́ípadě spíše formální.

\section{VLIV ZÁKLADNÍCH PRÁV NA PRÁVO EU V OBDOBÍ PŘED LISTINOU}

Podíváme-li se na starší judikaturu Soudního dvora EU v období před Lisabonskou smlouvou a zezávazněním Listiny základní práv EU, narazíme, pro někoho možná překvapivě, na poměrně velké množství rozsudků, které kontext lidských práv braly výrazně v potaz. ${ }^{25}$ Jedná se přitom o období, kdy primární právo EU, konkrétně článek 6 (bývalý článek F) Smlouvy o Evropské unii, ve znění Smlouvy z Nice, uváděl pouze:

„1. Unie je založena na zásadách svobody, demokracie, dodržování lidských práv a základních svobod a právního státu, zásadách, které jsou společné členským státům.

2. Unie ctí základní práva zaručená Evropskou úmluvou o ochraně lidských práv a základních svobod podepsanou v Řimě dne 4. listopadu 1950 a ta, jež vyplývají z ústavních tradic společných členským státům, jako obecné zásady práva Společenství."

\subsection{JUDIKATURA SOUDNÍHO DVORA EU V OBDOBÍ PŘED ZEZÁVAZNÉNÍM LISTINY}

Mezi rozhodnutími Soudního dvora, která znamenala značný posun v chápání základních svobod v rámci primárního práva EU, je možné zmínit zejména rozsudek C-60/00 ve věci Carpenter. ${ }^{26}$ Zde šlo o př́pad, kdy paní Carpenter, filipínské státní př́slušnici a manželce britského občana, nebyl udělen pobyt na území Velké Británie, nebot' unijní právo zaručuje pouze právo doprovázet manžela na území jiných člen-

23 Viz výše uvedená studie z roku 2016 The Implementation of the Charter of Fundamental Rights in the EU Institutional Framework, kapitola 1.5.3.

24 Viz Zprávy Komise o provádění Listiny základních práv EU z roku 2014, 2015 a 2016 (Report on the Application of the EU Charter of Fundamental Rights), poslední zpráva publikovaná ve formě Sdělení Komise COM(2017) 239 final z 18. 5. 2017.

25 MASING, J.: Unity and Diversity of European Fundamental Rights Protection. European Law Review, 2016, č. 4, s. 500 a násl.

26 C-60/00 Mary Carpenter proti Secretary of State for the Home Department, ECLI:EU:C:2002:434. 
ských států EU. Paní Carpenter však namítala, že její nárok na udělení pobytu vyplývá př́mo z komunitárního (dnes unijního) práva, nebot' se na území Británie stará o děti svého manžela, který poskytuje služby na území jiných členských států. Deportace paní Carpenter z Británie by naopak omezila právo jejího manžela vykonávat volný pohyb služeb v rámci EU, nebot' by tento musel ve zvýšené míre plnit rodičovské povinnosti ke svým dětem z prvního manželství.

Věc byla předložena k Soudnímu dvoru EU. Ten ve své argumentaci mimo jiné uvedl, že, ač Úmluva o ochraně lidských práv a základních svobod ${ }^{27}$ (dále také „Úmluva“") nezaručuje cizinci právo vstupu a pobytu na území určité země, ,mưže premístění osoby ze zemé, ve které bydli blizcí členové rodiny této osoby, vést k porušeni práva na respektování rodinného života, které je zaručeno článkem 8 odst. 1 Úmluvy “ (viz bod 42. rozsudku). Ochrana rodinného života byla jako korekce unijních pravidel pro volný pohyb osob využita i v dalších předlisabonských rozsudcích, nap̌r. v rozsudku C-413/99 ve věci Baumbast a . $^{28}$

Nebyl to ale jen volný pohyb osob v rámci EU, který byl zasažen lidskoprávní doktrínou. Limity dané ochranou základních práv byly předmětem rozhodování Soudního dvora EU i v jiných př́padech. Za zmínku stojí zejména rozsudek C-112/00 ve věci Schmidberger, ${ }^{29}$ ve kterém hrálo roli shromáždění za účelem vyvolání pozornosti veřejnosti ve věci ohrožení životního prostředí a veřejného zdraví kvůli zvyšujícímu se provozu na dálnici Brenner v Alpách.

Jádrem sporu byl tedy střet mezi zásadou volného pohybu zboží na straně jedné a, na straně druhé, právem na svobodu projevu a svobodu shromažd'ovací, které jsou zaručeny články 10 a 11 Evropské úmluvy o ochraně lidských práv a základních svobod. V uvedeném rozsudku v bodě 71 Soudní dvůr EU uvedl:

„,V tomto ohledu je třeba pripomenout, že podle ustálené judikatury jsou základní práva nedilnou součástí obecných právnich zásad, jejichž dodržování Soudní dvưr zajištuje, pričemž za tímto účelem vycházi z ústavních tradic společných členským státům, jakož i z poznatků, které skýtaji mezinárodně právní instrumenty týkající se ochrany lidských práv, na jejichž tvorbě členské státy spolupracovaly nebo k nimž přistoupily. Zvláštni význam prísluši v této souvislosti EÚLP. “

Z uvedeného Soudní dvůr vyvodil, že opatření neslučitelná s ochranou takto přiznaných lidských práv nejsou ve Společenství (dnes Unii) přijatelná (bod 73 rozsudku) a že ochrana těchto práv představuje oprávněný zájem, který v zásadě odůvodňuje omezení povinností stanovených právem Společenství (Unie), i pokud vyplývají z takové základní svobody zaručené Smlouvou, jako je volný pohyb zboží (bod 74 rozsudku).

Z výše uvedeného je zřetelné, že lidská práva a základní svobody byly již dříve korektivem pro naplňování čtyř základních svobod v rámci EU, tedy vytyčovaly limity pro uplatňování volného pohybu osob, zboží, služeb, nebo kapitálu a plateb. Ač se tento

27 Tj. Úmluva o ochraně lidských práv a základních svobod z roku 1950, v České republice (ČSFR) publikována pod č. 209/1992 Sb.

28 C-413/99 Baumbast a R proti Secretary of State for the Home Department, ECLI:EU:C:2002:493. Srov. WHELANOVÁ, M.: Obrácená diskriminace v oblasti volného pohybu osob ve světle poslední judikatury Evropského soudního dvora. Právní rozhledy (přiloha Evropské právo), 2003, č. 6, s. 13-16.

29 C-112/00 Eugen Schmidberger, Internationale Transporte und Planzüge proti Republik Österreich, ECLI: EU:C:2003:333. 
korektiv nabízel nejvíce u základních svobod vnitřního trhu, zasáhl dle potřeby i jiné oblasti mimo uvedenou sféru. Listina základních práv EU pak byla dle potřeby v argumentaci soudu někdy více, někdy méně silně zmiňována. ${ }^{30}$

Vedle oblasti volných pohybů za zmínku stojí zejména oblast pracovně-sociální, která vzhledem ke své povaze často vyvolávala otazníky ohledně rovného zacházení a zákazu diskriminace při výkonu závislé činnosti. Soudní dvůr se tudíž v některých prŕpadech jasné aplikaci obecných principů založených na lidskoprávním základě nemohl vyhnout.

Např́klad v rozsudku C-246/06 ve věci Josefa Velasco Navarro proti Fondo de Garantía Salarial (Fogasa) se projednával př́pad platebně neschopného zaměstnavatele a jeho zaměstnankyně. Uvedení mezi sebou uzavřeli smír, a to poté, co zaměstnavatel uznal neplatnost výpovědi dané své zaměstnankyni. Fond na ochranu zaměstnanců při platební neschopnosti zaměstnavatele, který měl na základě směrnice 2002/74/ES novelizující směrnici o ochraně zaměstnanců při platební neschopnosti zaměstnavatele ${ }^{31}$ za úkol ochránit nároky zaměstnanců, ale neuznal odstupné slíbené zaměstnavatelem $\mathrm{z}$ toho důvodu, že uvedená směrnice prímo formu smíru neupravovala. Když se věc dostala k Soudnímu dvoru, odkázal tento na obecný princip zákazu diskriminace a uvedl, že sporná právní úprava nevyhovuje komunitárním (dnes unijním) požadavkům. Konkrétně konstatoval, že ,, $[Z]$ toho důvodu musí taková právní úprava být ... v souladu s obecnými zásadami a se základními právy, jejichž dodržování Soudní dvưr zajištuje, mezi něž patř́ zejména obecná zásada rovnosti a zásada zákazu diskriminace " (bod 32 rozsudku). Dále Soudní dvůr uvedl, že nelze připustit, aby bylo se srovnatelnými situacemi zacházeno rozdílně, pokud toto rozdílné zacházení není objektivně odůvodněno. Jinými slovy, Soudní dvůr provedl takový výklad směrnice o platební neschopnost zaměstnavatele, který konvenoval obecným lidskoprávním zásadám, zejména zásadě rovnosti a zákazu diskriminace, a rozšriřil tak účinky směrnice do oblastí, které na první pohled nebyly směrnicí jasně pokryty. ${ }^{32}$ Obdobný lidskoprávní výklad týkající se promítnutí obecné zásady zákazu diskriminace do sekundárních unijních pravidel je možno spatřovat i v rozsudku C-555/07 ve věci Kücükdeveci, ${ }^{33}$ ve kterém šlo o př́pad diskriminace na základě věku podle směrnice 2000/78/ES. ${ }^{34}$ Konkrétně byl základem

${ }^{30}$ Listina tak byla někdy považována za dokument „,pouze“ uznávající stávající práva a povinnosti, který nemá žádnou právní sílu; jindy však na ni bylo odkazováno jako na pramen práva, který soudům umožňuje stanovit rozsah použití základních práv. Viz BAZZOCCHI, V.: The European Charter of Fundamental Rights and the Courts. In DI FEDERICO, G. (ed.): The EU Charter of Fundamental Rights. From Declaration to Binding Instrument. Dordrecht: Springer, 2011.

31 Směrnice Evropského parlamentu a Rady 2002/74/ES ze dne 23. 9. 2002, kterou se mění směrnice Rady 80/987/EHS o sbližování právních předpisủ členských států týkajících se ochrany zaměstnanců v př́ípadě platební neschopnosti zaměstnavatele, Ưř. věst. L 270, 8. 10. 2002, s. 10-13, zvláštní vydání v českém jazyce: Kapitola 05, svazek 004, s. 261-264.

32 Z tohoto pohledu vyznívá poněkud rozporuplně pozdější rozsudek C-198/13 Hernandez (C-198/13 Víctor Manuel Julian Hernández a dalši v. Reino de España (Subdelegación del Gobierno de España en Alicante) a dalši , ECLI:EU:C:2014:2055), ve kterém již hrála roli Listina základních práv Evropské unie. Zde totiž naopak bylo konstatováno, že speciální systém úhrad během platební neschopnosti zaměstnavatele vůbec nespadá do rámce práva EU a ustanovení Listiny základních práv Evropské unie se proto nepoužijí.

33 C-555/07 Seda Kücükdeveci proti Swedex GmbH \& Co. KG, ECLI:EU:C:2010:21.

34 Směrnice Rady 2000/78/ES ze dne 27. 11. 2000, kterou se stanoví obecný rámec pro rovné zacházení v zaměstnání a povolání, Ứr. věst. L 303, 2. 12. 2000, s. 16-22, zvláštní vydání v českém jazyce: Kapitola 05, svazek 004, s. 79-85. 
případu spor mezi zaměstnankyní a jejím zaměstnavatelem, který jí z důvodu jejího nižšího věku a v souladu s vnitrostátním právem stanovil kratší výpovědní dobu, než jakou stanovil zaměstnancům starším. Soudní dvůr posoudil uvedený př́ípad jako diskriminační a uvedl, že vnitrostátnímu soudu přísluší zajistit dodržování zásady zákazu diskriminace na základě věku, jež je konkretizována směrnicí 2000/78/ES, a př́ípadně nepoužít ustanovení vnitrostátního práva, které je s touto zásadou v rozporu (bod 53 rozsudku). ${ }^{35}$

Z uvedeného vyplývá, že lidskoprávní náhled je dlouhodobým trendem zejména v oblasti týkající se postavení zaměstnanců. Jak uvádí V. Šmejkal, již v předlisabonském období pracoval Soudní dvůr EU s řadou sociálních práv jako s obecnými zásadami práva EU, ,,tj. postuloval jejich status součásti primárního práva EU i bez toho, aby bylo nutné čekat na souhlas členských státu s právní závazností Listiny základních práv EU". 36

Vedle otázek diskriminace se starší judikatura Soudního dvora dotkla i lidskoprávních aspektů spojených s vyvažováním požadavků na řádné fungování státní správy na straně jedné a na ochranu práv jednotlivců na straně druhé. To je možno doložit $z$ doby ještě před přijetím Listiny základních práv EU na př́ípadu týkajícím se ochrany osobních údajů. Ve věci C-465/00, C-138/01, C-139/01 Rechnungshof ${ }^{37}$ byl Soudním dvorem EU posuzován př́pad rakouské právní úpravy, která veřejnoprávním rozhlasovým stanicím ukládala vedle povinnosti sdělit příslušné údaje orgánu dohledu (Rechnungshof) i povinnost zveřejnit platy a důchody zaměstnanců, které převyšovaly určitou úroveň. Soudní dvůr uvedenou úpravu posuzoval opět mj. i z hlediska čl. 8 Evropské úmluvy o lidských právech a základních svobodách, který se týká ochrany soukromí. V rozsudku uvedl, že za předpokladu, že je prokázáno, že široké zveřejnění ročních příjmů převyšujících určitý strop i jmen poživatelů těchto př́ijmů je nezbytné a vhodné ve vztahu $\mathrm{k}$ cíli řádné správy veřejných prostředků sledovanému ústavodárcem, nedochází k rozporu s (tehdy platnou) směrnicí Evropského parlamentu a Rady 95/46/ES, o ochraně fyzických osob v souvislosti se zpracováním osobních údajů a volném pohybu těchto údajů. ${ }^{38}$

35 Srov. KOKOTT, J. - SOBOTTA, Ch.: The Charter of Fundamental Rights of the European Union after Lisbon. R.R.D.E., 2012, č. 5, s. 110. Autoři poznamenávají, že uvedený rozsudek by neměl být chápán jako podstatný posun vytváŕející novou orientaci v oblasti aplikace katalogu základních práv, nebot’ pracovněprávní věci Soudní dvůr EU dlouhodobě posuzuje citlivěji z hlediska horizontálních účinků práva EU.

36 ŠMEJKAL, V.: Listina základních práv EU jako nástroj budování sociálního systému EU? Právník, 2016, č. 6, s. 493.

37 C-465/00, C-138/01 a C-139/01 Rechnungshof (C-465/00) proti Österreichischer Rundfunk a dalšim a Christa Neukomm (C-138/01) a Joseph Lauermann (C-139/01) proti Österreichischer Rundfunk, ECLI: EU:C:2003:294.

38 Směrnice Evropského parlamentu a Rady 95/46/ES ze dne 24. 10. 1995 o ochraně fyzických osob v souvislosti se zpracováním osobních údajů a o volném pohybu těchto údajů, Úř. věst. L 281, 23. 11. 1995, s. 31-50, zvláštní vydání v českém jazyce: Kapitola 13, svazek 015, s. 355-374. 
Z uvedeného je nutné vyvodit, že výklad Soudního dvora EU v kontextu lidských práv není záležitostí několika posledních let a neváže se pouze $\mathrm{k}$ okamžiku zezávaznění Listiny základních práv EU. Naopak, uvedený širší pohled v souvislostech je spojen se samotnou podstatou Unie, která je založena na svobodě, demokracii, dodržování lidských práv a základních svobod, a na zásadě právního státu. Tento pohled navíc již v předlisabonském období pronikal i do sekundárního práva $\mathrm{EU}$, jak je patrné z mnoha preambulí ke směrnicím z té doby, zejména těch, které se týkají zákazu diskriminace $^{39}$ nebo cizineckého práva. Např́klad bod 2 preambule ke směrnici o právu na sloučení rodiny ${ }^{40}$ uvádí:

„Opatření týkajicí se sloučení rodiny by méla být príjata ve shodě se závazkem chránit rodinu a respektovat rodinný život obsaženým v mnoha nástrojich mezinárodního práva. Tato směrnice ctí základni práva a ř́dí se zásadami uznanými zejména v článku 8 Evropské úmluvy o ochraně lidských práv a základních svobod a v Listině základních práv Evropské unie. “"

Nezbývá tedy než podotknout, že Listina základních práv EU, alespoň prozatím, nebyla hybatelem zásadnějších posunů v judikatuře Soudního dvora EU, nebot' mnohá přelomová rozhodnutí s lidskoprávním pojetím jsou mnohem staršího data. Jistou úlohu v tomto závěru hraje i ta skutečnost, že Listina primárně „,pouze“ potvrzuje a kodifikuje již existující katalog práv. ${ }^{41}$ Existence Listiny dále nepřiměla tvưrce sekundárního práva Evropské unie $\mathrm{k}$ hlubšímu zamyšlení ohledně kontextu, ve kterém se velké množství nově přijímaných právních norem nachází. Výsledek je ten, že jsou stále vydávány předpisy Evropské unie, které jsou následně korigovány judikaturou Soudního dvora EU, nebo u kterých se dá, vzhledem k jejich spornému či nejasnému charakteru, taková korekce prostřednictvím soudního výkladu očekávat.

\section{ZÁVĚR}

Dopady Listiny základních práv EU v oblasti implementace práva EU se projevují různě $\mathrm{v}$ různých pramenech práva EU. Zatímco v př́ípadě judikatury Soudního dvora EU je argumentace Listinou v rozhodování o konkrétních prŕpadech častá a podrobná, $\mathrm{v}$ př́ípadě sekundární legislativy EU se $\mathrm{v}$ preambulích ve vztahu $\mathrm{k}$ Listině objevuje spíše formální a povrchní zhodnocení navrhovaných úprav.

Nutné je rovněž poukázat na to, že i starší judikatura Soudního dvora EU zřetelně zdůrazňovala obecné principy a kontext lidských práv, v rámci kterých byla konkrétní úprava posuzována. Principy shodné či obdobné Listině základních práv EU se tudíž v rozhodování soudu objevovaly i v období dávno před přijetím Listiny. Týkaly se však

39 Srov. široké odkazy na mezinárodní kontext v preambuli ke směrnici 2000/78/ES, viz výše pozn. č. 34.

40 Směrnice Rady 2003/86/ES ze dne 22. 9. 2003 o právu na sloučení rodiny, Úř. věst. L 251, 3. 10. 2003, s. 12-18, zvláštní vydání v českém jazyce: Kapitola 19, svazek 006, s. 224-230.

${ }^{41}$ Srov. obdobný závěr KOKOTT, J. - SOBOTTA, Ch.: The Charter of Fundamental Rights of the European Union after Lisbon. R.R.D.E., 2012, č. 5, s. 111. 
nejčastěji prŕpadů, kdy byla vykládána pravidla související s principy vnitřního trhu, zejména volným pohybem osob, nebo zásadou zákazu diskriminace.

Vzhledem $k$ výše uvedenému je možno učinit závěr, že ač dochází $k$ argumentačním posunům, které přináší Listina základních práv EU, praktické dopady na implementaci práva EU do vnitrostátních právních řádů alespoň zatím nejsou oproti dřivějšímu stavu výrazné.

JUDr. Markéta Whelanová, Ph.D.

Odbor kompatibility Úřadu vlády ČR

whelanova.marketa@vlada.cz 